RECEIVED

DEC 112000

QSTI

\title{
Supercritical Water Oxidation Data Acquisition Testing
}

K. M. Garcia

Published August 1996

\section{Idaho National Engineering Laboratory Strategic Environmental Research and Development Program Lockheed Martin Idaho Technologies Company Idaho Falls, Idaho 83415}


$\ldots$ 


\section{DISCLAIMER}

This report was prepared as an account of work sponsored by an agency of the United States Government. Neither the United States Government nor any agency thereof, nor any of their employees, make any warranty, express or implied, or assumes any legal liability or responsibility for the accuracy, completeness, or usefulness of any information, apparatus, product, or process disclosed, or represents that its use would not infringe privately owned rights. Reference herein to any specific commercial product, process, or service by trade name, trademark, manufacturer, or otherwise does not necessarily constitute or imply its endorsement, recommendation, or favoring by the United States Government or any agency thereof. The views and opinions of authors expressed herein do not necessarily state or reflect those of the United States Government or any agency thereof. 


\section{DISCLAIMER}

Portions of this document may be illegible in electronic image products. Images are produced from the best available original document. 


\section{CONTENTS}

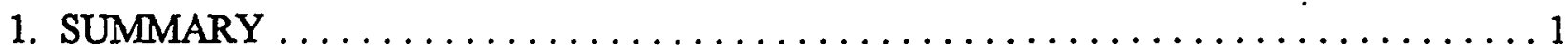

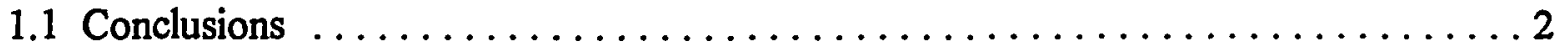

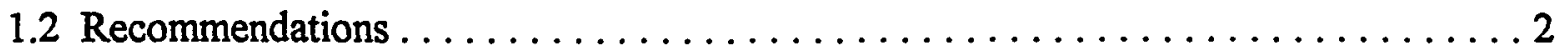

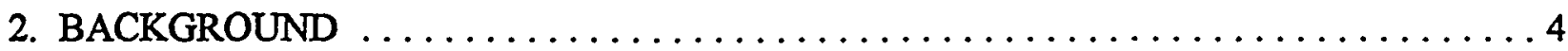

2.1 Introduction to Supercritical Water Oxidation ...................

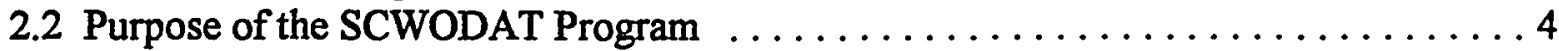

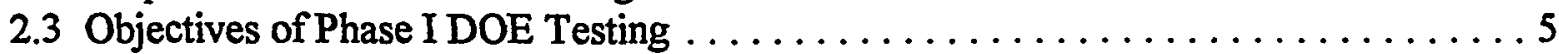

2.4 Objectives of Phase II Navy Waste Testing $\ldots \ldots \ldots \ldots \ldots \ldots \ldots \ldots \ldots$

3. ENGINEERING AND DESIGN $\ldots \ldots \ldots \ldots \ldots \ldots \ldots \ldots \ldots \ldots \ldots \ldots$

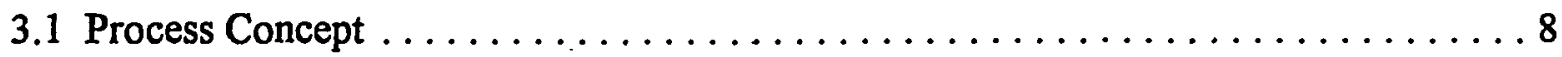

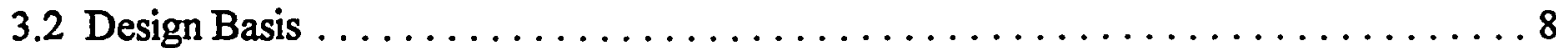

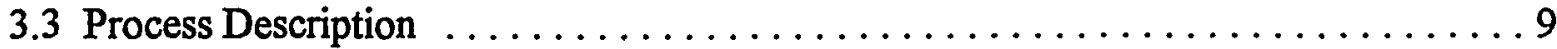

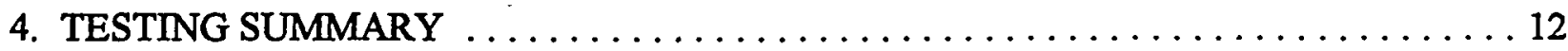

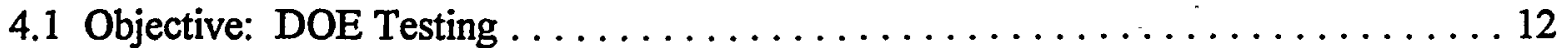

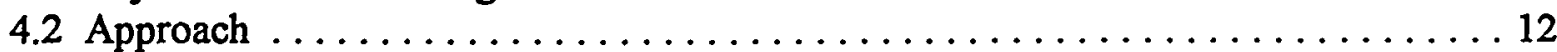

5. ANALYSIS: MODAR SCWO TESTING RESULTS $\ldots \ldots \ldots \ldots \ldots \ldots \ldots \ldots$

5.1 Process Optimization: Key TRIM@SOL Test Runs $\ldots \ldots \ldots \ldots \ldots \ldots \ldots \ldots$

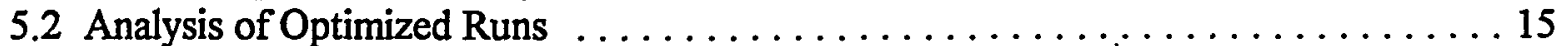

5.2.1 Flow Conditions and Surrogate Composition $\ldots \ldots \ldots \ldots \ldots \ldots \ldots$

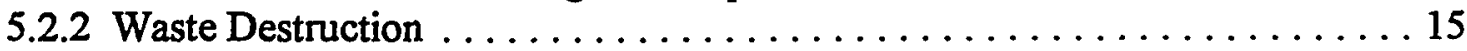

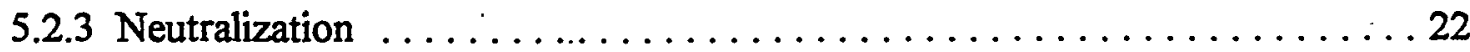

5.2.4 Distribution of Surrogate Metals and Inorganics $\ldots \ldots \ldots \ldots \ldots \ldots 24$

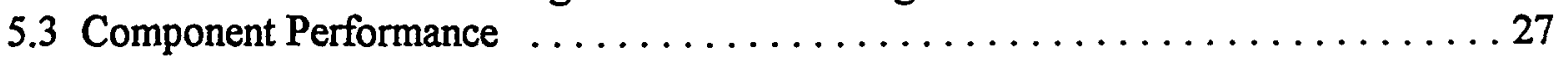

5.3.1 Liner Performance ............................ 27

5.3.2 December 1995 Inspection of Other Pilot Plant Components . . . . . . . . 37

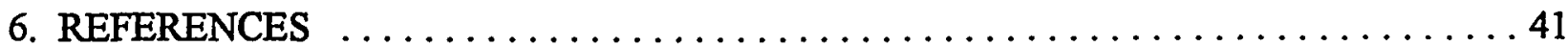

\section{FIGURES}

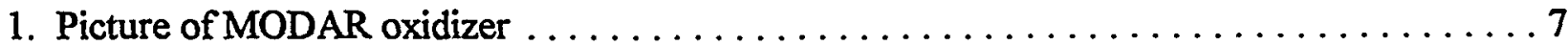

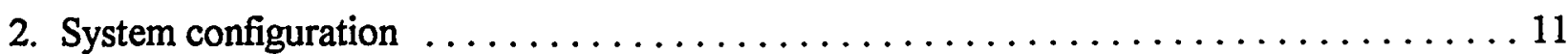

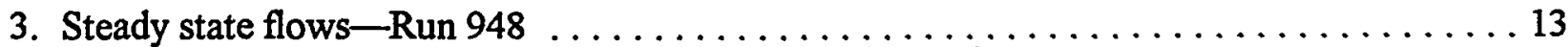

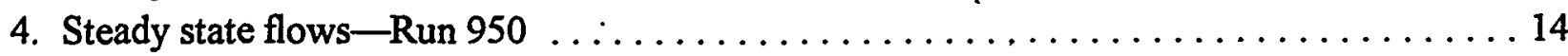

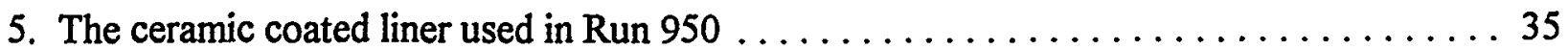

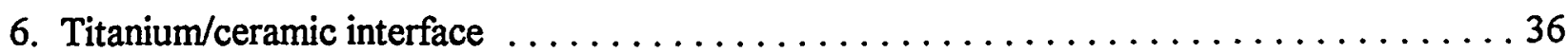

TABLES

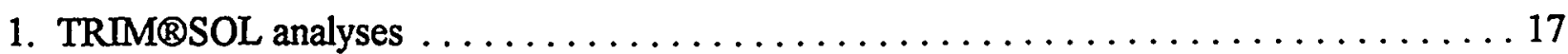

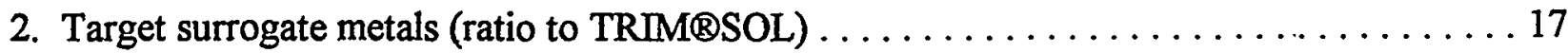




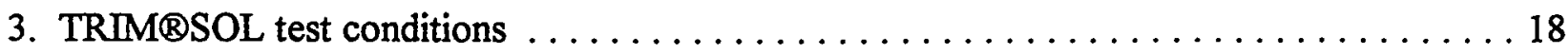

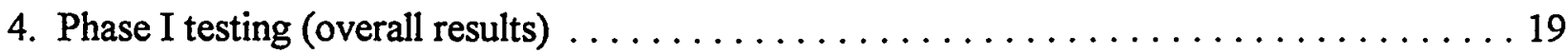

5. Phase I testing-aqueous effluent quality organic analyses $\ldots \ldots \ldots \ldots \ldots \ldots \ldots \ldots$

6. Phase I testing-aqueous effluent quality inorganics in solution $\ldots \ldots \ldots \ldots \ldots \ldots 21$

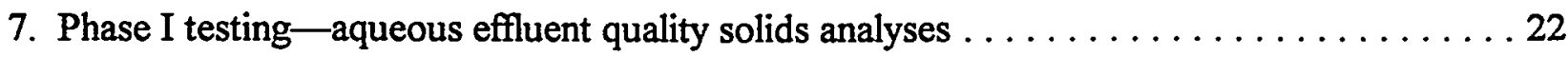

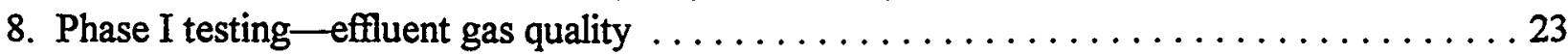

9. Run 948 distribution of elements unneutralized TRIM®SOL (in the oxidizer) . . . . . . 25

10. Run 950 distribution of elements neutralized TRIM $\otimes S O L$ (in the oxidizer) . . . . . . . 25

11. Summary of results from examinations at Geller Laboratories ................ 29 


\section{Supercritical Water Oxidation Data Acquisition Testing}

\section{SUMMARY}

Supercritical Water Oxidation (SCWO) technology holds great promise for treating mixed wastes in an environmentally safe and efficient manner. In the spring of 1994 the U.S. Department of Energy (DOE); Idaho Operations Office awarded Stone \& Webster Engineering Corporation, of Boston Massachusetts and its sub-contractor MODAR, Inc. of Natick

1 Massachusetts a Supercritical Water Oxidation Data Acquisition Testing (SCWODAT) program. The SCWODAT program was contracted through a Cooperative Agreement that was co-funded by the DOE and the Strategic Environmental Research and Development Program.

The SCWODAT testing scope outlined by the DOE in the original Cooperative Agreement and amendments thereto was initiated in June 1994 and successfully completed in December 1995.) The SCWODAT program provided further information and operational data on the effectiveness of treating both simulated mixed waste and typical Navy hazardous waste using the MODAR SCWO technology.

The SCWODAT program was undertaken in two Phases. Phase I included the DOE simulated mixed waste testing and Phase II the Navy hazardous waste testing. The program concentrated on the acquisition of data through pilot plant testing. The Phase I DOE testing used a simulated waste stream that contained a complex machine cutting oil and metals, that acted as surrogates for radio nuclides. The Phase II Navy testing included pilot testing using hazardous waste materials to demonstrate the effectiveness of the MODAR SCWO technology. The SCWODAT program also included extensive engineering and fabrication activities to prepare the MODAR pilot plant for both the Phase I and Phase II programs.

During Phase I of the SCWODAT program a simulated waste stream consisting of TrimSol, a chlorinated machine cutting oil, was processed over seven test runs. The objective of the program was to destroy the organic constituents present in the simulated waste stream. A second objective of the Phase I testing program was to determine the distribution of the surrogate radioactive constituents in the treated effluents. The TrimSol waste testing conducted at MODAR's facility utilized only simulated mixed wastes, no actual radioactive wastes were processed.

Following the Phase I DOE simulated mixed waste SCWO testing program, the Phase II Navy waste testing program was conducted. The objective of Phase II was to collect treatability data for the application of the MODAR SCWO technology to actual Navy wastes generated at a typical shore side Navy waste depot. The Navy intends to utilize the SCWODAT program test data to determine the advantages of a MODAR SCWO oxidizer for future Navy SCWO projects. 
In addition, since the wastes tested are similar to many DOE generated hazardous wastes, the Phase II Navy testing program also supports DOE's treatment options for mixed wastes.

INEL designed a SCWO test bed system to be used to test privately developed SCW oxidizers to determine the optimum configuration for treating DOE mixed radioactive waste and to support their commercialization through demonstration. In November 1994 the scope of this cooperative agreement was modified to include a technical review of the INEL designed SCWO test bed system by the SCWODAT team.

\subsection{Conclusions}

- The SCWODAT program demonstrated that the MODAR SCWO process oxidized the simulated waste stream containing TRIM@SOL, selected by DOE as representative of one of the most difficult of the organic waste streams for which SCWO had been applied. The TRIM@SOL with surrogate metals in solution was oxidized, with a high destruction efficiency, on the order of $99.97 \%$, in both the neutralized and unneutralized modes of operation. The high TRIM®SOL destruction efficiencies achieved during the SCWODAT program strongly supports the cgnclusion that the MODAR SCWO process is applicable to a wide range of organic wastes, most of which are more readily oxidized and less chemically aggressive.

- For the equipment as configured, a relatively high kinetic energy nozzle was necessary to achieve good destruction efficiency.

- A liner was essential for protection of the high nickel alloy SCW oxidizer pressure vessel from the aggressive environment, as demonstrated by previous material problems encountered when a liner was not utilized.

- A graded ceramic coating appeared to perform better than a titanium liner when exposed to salts.

- The oxidation of TRIM@SOL created "sticky salts" whether or not a neutralizing agent was added to the process feed. Periodic flushing of the oxidizer during operation may be necessary to mitigate the accumulation of solids.

- To achieve volume reduction in the treatment of TRIM@SOL mixed waste an evaporation step in conjunction with a recycling system will be necessary to separate the water from the organic-free radioactive solid by-products, such as the evaporation system incorporated into the INEL Test Bed design.

- High nickel alloys tested to date were unacceptable as pressure bearing parts directly exposed to the process environment. However, titanium components, such as the 
pressure bearing piping and the heat exchanger in the quench system, performed very well during testing. There was no evidence of corrosion attack in areas accessible for examination.

- The MODAR SCWO process produced discharge effluents that were within sewer permit compliance limits as demonstrated by the two Massachusetts Water Resources Authority (MWRA) unannounced inspections and effluent sampling conducted during the Phase II testing. (MWRA Sample ID No.39510703 on 11/27/95 and No.39510699 on $12 / 19 / 95$.)

\subsection{Recommendations}

- We believe the present testing program has demonstrated process applicability and maturity sufficient to warrant the construction of a dedicated demonstration unit.

- We recommend that the SCWODAT program testing be expanded to test solid wastes such as radioactively contaminated wipes, gloves, and other miscellaneous generated at typical DOE sites.

- We recommend construction of a plant such as the INEL Test Bed facility, which can address the technical issues associated with SCWO treatment of mixed wastes, such as deposition of radioactive metals in the SCWO oxidizer.

- From the data gathered during this project it is believed that running unneutralized with a coated liner should be the selected mode of operation for future designs. Heavy metals in combination with $\mathrm{Na}$ and $\mathrm{K}$ appear to create an environment which can be too aggressive for an uncoated, all metallic liner (Run 949). Other than the limited delamination problem with the coated liner, scale up from the 1994 corrosion test program of 1994 to a relatively large working piece was quite successful. Further testing of the coated liner is needed:

- To determine the long term operability when running unneutralized

- To determine the long term operability when running neutralized

- To determine if the areas of delamination that occurred in Run 950 were due to the process environment, the application of the coating, or some other factor.

- Further investigation and study is needed to improve the MODAR reformer system if running neutralized. 


\section{BACKGROUND}

\subsection{Introduction to Supercritical Water Oxidation}

Supercritical Water Oxidation (SCWO) is a high pressure oxidation process that blends air, water, and organic waste material in an oxidizer in which where the temperature and pressure in the oxidizer are maintained above the critical point of water. Supercritical water mixed with hydrocarbons, which would be insoluble at subcritical conditions, forms a homogenous phase which possesses properties associated with both a gas and a liquid. Hydrocarbons in contact with oxygen and SCW are readily oxidized. These properties of SCW make it an attractive means for the destruction of waste streams containing organic materials.

While the very simple configurations of the process can easily treat non-halogenated organic compounds, the processing of salt-forming wastes using SCWO has proved to be more complex. Inorganic salts which are soluble at sub-critical conditions, become insoluble and precipitate from SCW solution. As an organic enters the SCWO environment, carbon and hydrogen are oxidized and any inorganic anions present, such as chloride, sulfate, or phosphate. Neutralization of the acids with added cations, such as sodium, calcium, or magnesium, forms "sticky salts." The MODAR process was designed to operate in these harsh conditions.

The SCWO process has inherent advantages over alternative thermal oxidation technologies, such as incineration, in that it is applicable to a wide range of organic materials, the oxidation process occurs within a comparatively small volume environment, and organics are oxidized to very high destruction efficiencies. The benign byproducts of the process are primarily $\mathrm{CO}_{2}, \mathrm{~N}_{2}$, neutral salts, and water. The production of acid gases, particulates, and volatile emissions are negligible. For example, the concentration of the priority pollutants $\mathrm{NO}_{\mathrm{x}}, \mathrm{SO}_{2}$, and $\mathrm{CO}$ in the air emissions from the MODAR SCWO process are less than that emitted from a typical gas-fired home water heater. Thus, SCWO is applicable for the destruction of a wide range of hazardous materials which can be oxidized in a controlled manner yielding residuals that are environmentally safe for disposal.

For handling mixed radioactive wastes, the favorable air emissions profile of SCWO is particularly advantageous. Computer simulation indicates that SCWO is expected to produce lower radioactive ir emissions than incineration with advanced off gas treatment (Dehmel and Hong 1994). In comparison with other technologies which are being considered for mixed waste treatment, SCWO has a high level of safety and stability, and can handle high carbon levels without risk of explosion. Supercritical steam power plants are very common, and have been in commercial use since the 1950s. Furthermore, the MODAR SCWO system is designed to provide leak-before-break operation.

\subsection{Purpose of the SCWODAT Program}


The primary purpose of the SCWODAT program was to provide further information on the effectiveness of MODAR's SCWO treatment of a simulated mixed waste (Phase I) of interest to the U.S. Department of Energy and in the treatment of shore side hazardous wastes (Phase II) of interest to the U.S. Navy.

SCWODAT program personnel conducted all testing using MODAR's existing pilot plant located in Natick, Massachusetts. The project concentrated on the acquisition of data through testing with surrogate mixed waste and actual Navy waste materials. Similar to previous SCWO programs conducted by Stone \& Webster and MODAR, Stone \& Webster was the project manager and MODAR was the sub-contractor. In December, 1995 General Atomics, of San Diego California purchased MODAR, Inc. MODAR and its associated SCWO treatment facilities were relocated in March 1996 to General Atomics' facilities in San Diego. Within this report reference will continue to be made to "MODAR, Inc." and "MODAR technologies" in recognition of the experience and reputation associated with the MODAR name and MODAR SCWO technologies. The usage of the MODAR name should also be taken to be a reference to General Atomics.

\subsection{Objectives of Phase I DOE Testing}

DOE was interested in destruction of mixed wastes, including TRIMßSOL, a water soluble cutting oil containing primarily carbon, chlorine, hydrogen, oxygen, sulfur, and phosphorous. TRIM $B S O L$ is difficult to oxidize because it is formulated with surfactants, anti-oxidants, viscosity modifiers, anti-friction agents, and stabilizers. TRIM®SOL, used in solution for machining plutonium, becomes contaminated with radio nuclides. DOE would like to reduce the volume of this waste by destroying the organic constituents.

The purpose of this program was to determine the organic destruction efficiency of contaminated TRIMBSOL that can be attained using MODAR'S SCWO process, and to determine how surrogate radio nuclides would be distributed. The TRIM@SOL waste testing conducted at MODAR's facility only utilized materials that simulated mixed wastes, no actual radioactive wastes were processed during this testing program.

The specific Phase I SCWODAT objectives were:

- To demonstrate complete destruction of the organic constituents

- To demonstrate effective neutralization of acid forming anions

- To control solids generated during in-situ neutralization 
- To determine the effect on destruction efficiency and distribution of surrogate metals contained in the simulated mixed waste

- To evaluate materials of construction in all environments of the process.

As part of the Phase I activities, SCWODAT program personnel also participated in an engineering review of an INEL designed SCWO Test Bed System. DOE plans to use this Test Bed System in the future to test privately developed SCWO oxidizers. This will permit the determination of the optimum oxidizer design for treating a variety of DOE mixed radioactive waste (Barnes, C. M., "Mixed Waste Survey for the SCWO Program," Idaho National Engineering Laboratory Publication EGG-WTD-10984, November 1993) and support of the commercialization of privately developed oxidizers through technology demonstrations. The SCWO Test Bed System will be developed to eventually allow DOE testing of actual mixed wastes (radioactive) within the controlled environment of a DOE facility.

\subsection{Objectives of Phase II Navy Waste Testing}

Following the Phase I DOE simulated mixed waste tests, the Phase II testing program was conducted on actual Navy hazardous wastes. The objective was to demonstrate the ability of the MODAR SCWO technology to treat Navy wastes generated at a typical shore side Naval facility. The Navy can utilize the MODAR test data to determine the advantages of a vessel oxidizer in future Navy SCWO projects. In addition, since the wastes tested are similar to many DOE generated hazardous wastes, these data will support DOE's treatment options for mixed wastes. 


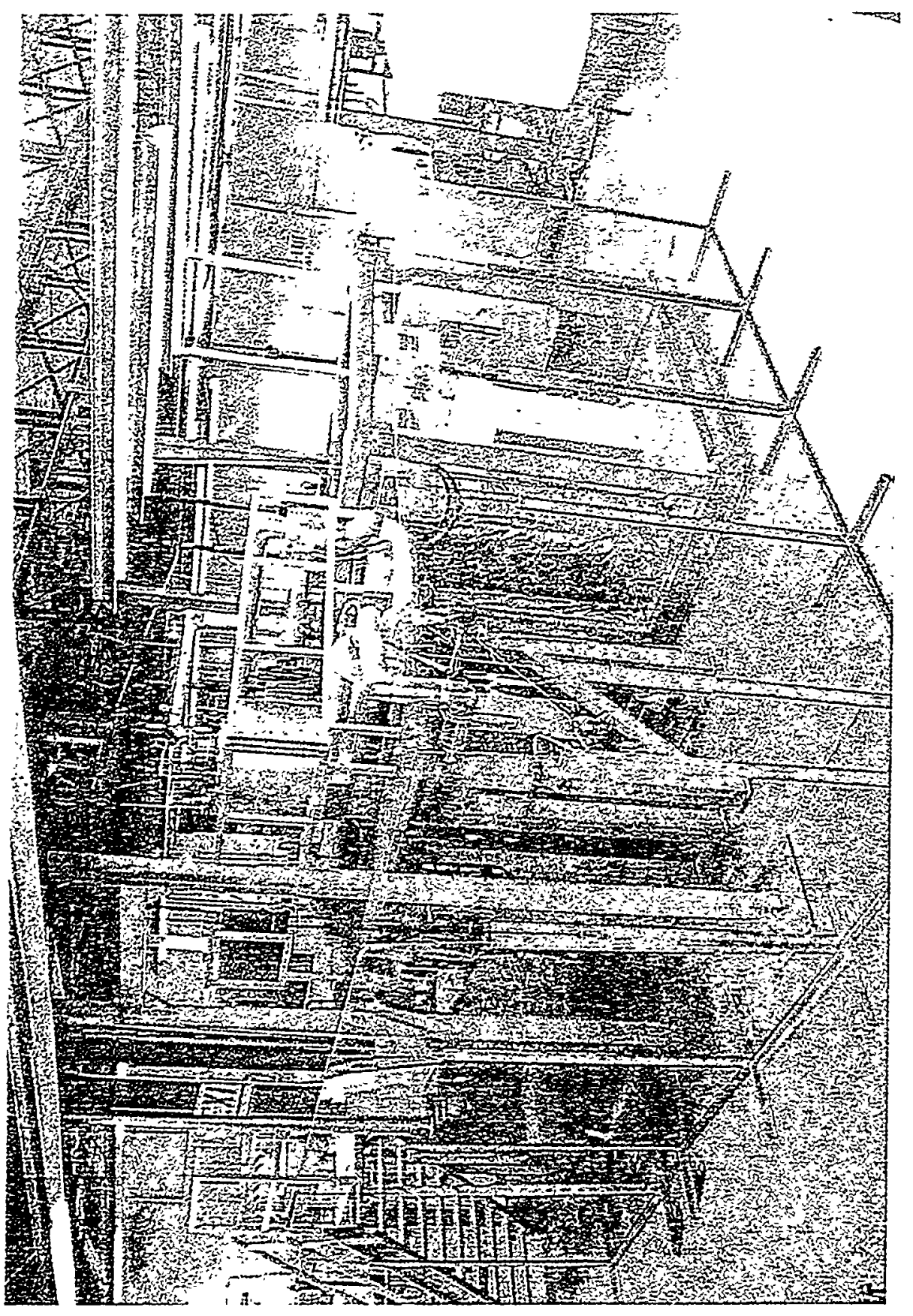

善

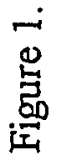




\section{ENGINEERING AND DESIGN}

\subsection{Process Concept}

Through various U.S. government and privately sponsored research and development programs, MODAR demonstrated the ability of its SCWO process to effectively destroy a wide range of organic materials. In these previous programs, MODAR developed the methods to control the deposition of "sticky salts," and minimize corrosion. These earlier developments, which were performed using MODAR's bench scale and pilot scale plants, enabled MODAR to develop a process concept for the treatment of mixed wastes.

At the beginning of the SCWODAT program, a process concept was developed to test alternative configurations that were expected to achieve the required treatment. The existing pilot plant was modified to include:

- Pretreatment of TRIM@SOL prior to its oxidation, to attain neutralization of hydrochloric acid formed from the chlorine contained in TRIMBSOL.

- Use of a low energy oxidizer nozzle to minimize turbulence, and hence salt deposition, in the oxidizer.

- Quenching the overhead effluent to prevent salt deposits from obstructing the oxidizer effluent line.

- Addition of a neutralizing agent in the overhead effluent quench to control effluent $\mathrm{pH}$.

- Use of a liner to protect the alloy pressure vessel from the process environment.

- Removal, from the pilot plant, of a heat exchanger (feed versus effluent) which had experienced corrosion failure during a previous program. The capacity of the air/water heater was increased to compensate for the loss of regenerative heat exchange.

\subsection{Design Basis}

Since the primary objective of the program was data acquisition, the following design basis was established:

- $\quad$ TRIM@SOL would be metered to the process as undiluted virgin material, to obtain an accurate measure of organic destruction efficiency. 
- Surrogate metals would be purchased as metal acetates, to be dissolved in deionized water and metered to the process, in order to obtain an accurate element material balance.

- The oxidizer liner would be designed to be removable, so that the performance of an all metallic liner and a ceramic coated liner could be compared.

- A portion of the high pressure air would be used to purge annular spaces between the oxidizer vessel and the oxidizer liner. Air flow to the process would not be optimized relative to the stoichiometric oxygen requirement.

- To keep the interpretation of the analytical chemistry results and concomitant material balances simple, water flows were once-through the process. Effluent water would not be reused. Also, the quench water flow would not be at its theoretical minimum.

- Because of the high heating value of TRIM $囚 S O L$, heat recovery from the process effluent would not be needed.

\subsection{Process Description}

Throughout the testing program, the design was modified to obtain the optimum configuration for processing simulated mixed waste. The following describes the process configuration used for the "optimum" data acquisition test Runs 948 and 950.

TRIM@SOL was pumped undiluted, to approximately $3,500 \mathrm{psig}$, by a diaphragm metering pump. Deionized water, containing the surrogate metals in solution, was pumped to the oxidizer by a separate diaphragm metering pump. The metals solution and neat TRIM@SOL were mixed in the feed line prior to being fed to the core of the oxidizer nozzle.

A stream of deionized water was pumped to the SCW/air heater, mixed with compressed air, and heated to $600^{\circ} \mathrm{C}$ by radiant heat transfer.

The oxidizer used in the program was a vertical pressure vessel with a removable liner designed to prevent the reactants and process effluent from coming into contact with the pressure vessel Alloy 625 material. A small stream of compressed air was used to prevent process fluid from seeping into the space between the oxidizer pressure vessel and the oxidizer liner. This "purge air" flowed into the oxidizer through various small openings in the liner. Oxidation occurred in the reaction zone of the liner (below the tip of the feed nozzle). The temperature in the oxidizer was maintained at approximately $600^{\circ} \mathrm{C}$, by adjusting the ratio of TRIMßSOL to water in the nozzle core. The main effluent stream, referred to as the overhead effluent, was withdrawn from the top of the oxidizer. This stream was immediately and rapidly quenched to 
approximately $300^{\circ} \mathrm{C}$, by addition of quench water to the quench fitting in the oxidizer outlet nozzle.

Salts that formed during neutralization, as well as a portion of the metal surrogates, precipitated from the supercritical fluid and either dropped into the brine zone at the bottom of the oxidizer, or stuck to the walls of the liner. A small stream of water was added to the bottom of the oxidizer to form the brine zone, where supercritical fluid became liquid phase water. Salts formed during in-situ neutralization dissolved in the liquid phase and were withdrawn as brine from the bottom of the oxidizer. The quench water was deionized water containing sodium bicarbonate to adjust the $\mathrm{pH}$ of the liquid effluent.

The overhead effluent was further cooled to approximately $45^{\circ} \mathrm{C}$ in an effluent cooler, the pressure was reduced, and the liquid and gas were separated. A slip stream of the gas went through on-line analyzers for measurement of carbon monoxide, residual oxygen, and other gases. The overhead liquid effluent was sampled for total organic carbon and metals analysis.

The brine from the bottom of the oxidizer was reduced in pressure, sampled, and collected in a holding tank. After each "optimized" run, the contents of the oxidizer were sampled and analyzed to complete the metals material balance. 


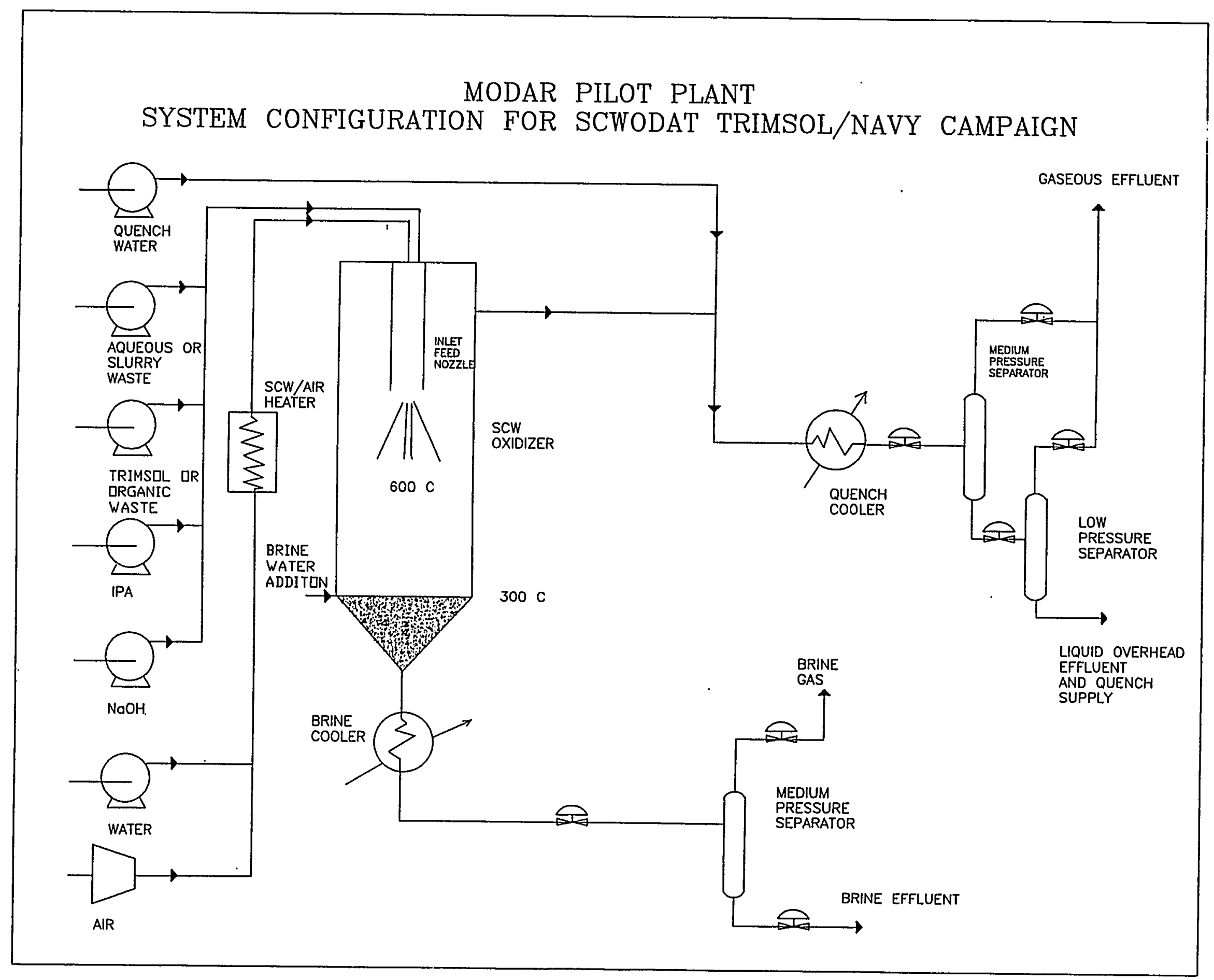

Figure 2. System Configuration 


\section{TESTING SUMMARY}

The following sections describe the objectives and approach for the Phase I SCWODAT program activities.

\subsection{Objective: DOE Testing}

Seven test runs were performed for the DOE portion of the SCWODAT program to validate organic destruction and evaluate system performance in controlling solids generated in the oxidizer. The testing focused on the evaluation of operating conditions and system hardware to identify any constraints or limitations as well as to optimize process performance.

\subsection{Approach}

Based on previous MODAR SCWO testing, the ability to process wastes containing acid precursors was dependent on being able to neutralize the acids formed and successful removal of the salt formed. The neutralization of the acids and control of solids deposition had previously been controlled by the same process device, the oxidizer inlet feed nozzle. This nozzle provided the proper mixing of organic feed material and the SCW/Air mixture. The characteristic nozzle velocities affect both neutralization and salt flow in the oxidizer.

For the SCWODAT program, more flexibility was given to the MODAR process with two separate sub-systems, the reformer and the quench system. The reformer heated the TRIMßSOL feed while mixing it with caustic. Chlorine was broken away from the TRIM@SOL and was neutralized in-situ by sodium hydroxide. The quench system was designed to rapidly cool the overhead effluent exiting the oxidizer to quickly dissolve particulate salt which might plug the small diameter downstream piping. 


\section{ANALYSIS: MODAR SCWO TESTING RESULTS}

Following mechanical testing to ensure safe and proper system operation, a series of runs were performed to optimize the surrogate mixed waste treatment. The two key runs of the program, Runs 948 and 950 , are analyzed in the following sections.

\subsection{Process Optimization: Key TRIM®SOL Test Runs}

The data gathered from Runs 943 through 947 was used to determine the test conditions for the first key test, Run 948. See Figure 3 for the flow values of Run 948. In this test, neutralization of acid was not attempted in the oxidizer but was accomplished by adding sodium bicarbonate to the quench water and brine makeup water only.

Run 949 is considered a preliminary run to gather data for running with neutralization in the oxidizer. Run 949 and Run 950 were identical in test conditions except for the use of a ceramic coated liner in Run 950 instead of the titanium liner used in Run 949. The flow values for Run 950 are shown in Figure 4.

In the second key run, Run 950, caustic was delivered with the TRIM@SOL feed to provide neutralization in the oxidizer. Neutralization of the overhead aqueous effluent was completed by adding sodium bicarbonate in the quench water.



Figure 3. Steady state flows-Run 948. 


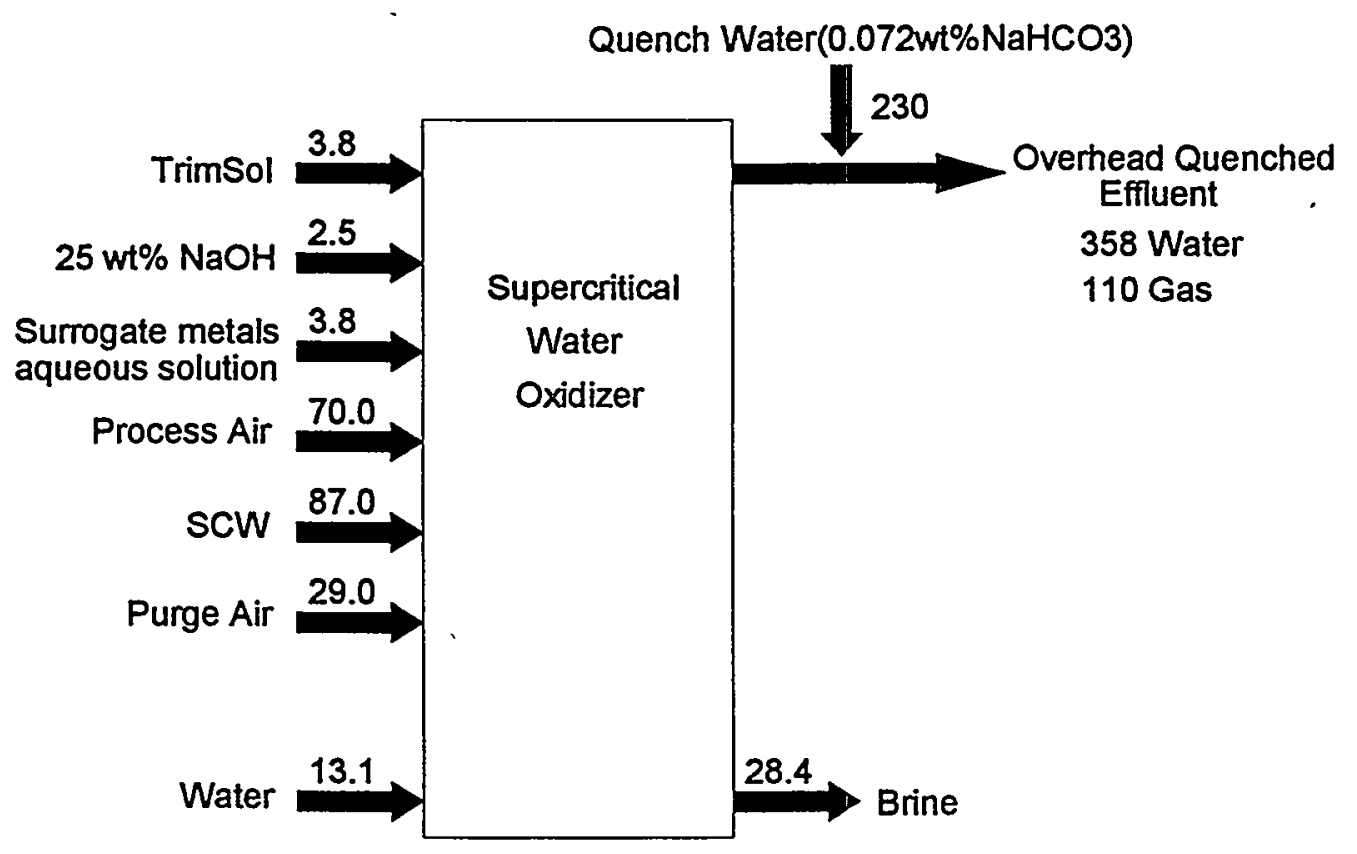

Notes: (1) All flows are $\mathrm{kg} / \mathrm{h}$.

(2) To simplify the interpretation of the chemical analyses, all water used was deionized to 1 micro S/cm and was used "once-though" the process.

Figure 4. Steady state flows-Run 950.

To simplify the interpretation of the analytical chemistry, demineralized water was used for all aqueous input streams with all streams being once-through flow. The quench stream was a relatively large flow and made up the majority of the volume of the SCWO process effluent flow. Calculation of waste destruction efficiencies was skewed by the use of high quench water flow in combination with the analytical detection limits for analysis of waste residuals. The resultant destruction efficiencies calculated with high quench water flows were therefore, skewed to a lower value than could be demonstrated if SCWO process effluent water had been reused.

Energy Laboratories, Inc. of Casper, Wyoming analyzed the TRIM®SOL waste feed, the liquid effluent, and the solid process effluent for Run 948 and Run 949. INEL's laboratory analyzed the Run 950 samples for most of the inorganic species of interest in this program, while Alpha Analytical Laboratories, of Westborough, MA performed additional inorganic analyses. Because neither of the two laboratories performed organic analyses for Run 950 and the operating conditions for Run 950 were nearly identical to Run 949, the organic results for Run 949 were tabulated as representative of Run 950 . Gas analysis was done using on-line analyzers. 
In all calculations of mass balances and destruction efficiency, analytical detection limits have been used when the analytical laboratory reported "Not Detected."

\subsection{Analysis of Optimized Runs}

Of the seven runs performed for the TRIM@SOL portion of the SCWODAT program, five were associated with testing to identify the effectiveness of new processes and/or determine optimum process conditions. The following analyses compares the results of the two optimized runs, Runs 948 and 950, in the areas of waste destruction, neutralization, and distribution of surrogate metals and inorganics.

\subsubsection{Flow Conditions and Surrogate Composition}

Figures 3 and 4 depict "black box" representations of the MODAR SCWO process for Runs 948 and 950 respectively. While the exact composition of TRIM@SOL is proprietary to its manufacturer, Table 1 shows two elemental analyses carried out as part of this program. As shown in this table, TRIM@SOL contains high concentrations of $\mathrm{Cl}$ and $\mathrm{S}$ which form acids during SCWO treatment.

The metals surrogate concentrations used for this program were established by INEL as a mass ratio to TRIMBSOL. These ratios are shown in Table 2 with all the metals being added as water soluble acetates in demineralized water. Cerium, the highest concentration metal, is the surrogate for plutonium. However, it is not known how its disposition might differ from plutonium in a SCWO system.

Compressed air was the oxidant used in the SCWODAT program. Supercritical water helped initiate the oxidation and provided the reaction medium. High pressure purge air was used in the annulus between the pressure vessel I.D. and the liner O.D. to maintain a slightly higher pressure outside the liner than inside. This kept corrosive materials away from the Alloy 625 oxidizer vessel.

Quench water contained $\mathrm{NaHCO}_{3}$ as shown in the Figures 3 and 4. Sodium bicarbonate was delivered with the brine make-up water only when $\mathrm{NaOH}$ was not used in the upper part of the oxidizer (Run 948). Table 3 summarizes the overall TRIM@SOL test conditions for optimized Runs 948 and 950.

\subsubsection{Waste Destruction}

At least 99.97 percent organic carbon destruction efficiency was achieved in both Runs 948 and 949 (and therefore 950) See Table 4. TRIMßSOL alone provided the fuel value to maintain the oxidation temperature of $600^{\circ}$ to $620^{\circ} \mathrm{C}$. Aqueous effluent TOC was at or below the analytical detection limit of $2 \mathrm{mg} / \mathrm{L}$ (Table 5). Table 6 summarizes the data on the inorganics in 
solution found in both the overhead and brine effluents for Runs 948 and 950 . Table 7 provides data on the solids analyses for both the overhead and brine effluents for both of the optimized Runs 948 and 950.

TRIM $B S O L$ proved to be one of the more refractory organic feeds encountered by MODAR. The propylene glycol ether and propylene glycol constituents of TRIM@SOL may account for its resistance to oxidation. The addition of sodium hydroxide to the oxidizer in Run 949/950 slightly inhibited the oxidation of TRIMBSOL. This was observable, however, only at the parts per billion concentration level for several non-chlorinated species and at $0.05 \mathrm{mg} / \mathrm{L}$ for total organic halogen, TOX. 
Table 1. TRIM@SOL analyses (all values are weight \%).

\begin{tabular}{lll} 
MODAR Sample Number & $\mathbf{9 4 4 - 1}$ & $\mathbf{9 4 4 - 2}$ \\
Energy Labs Number & $\mathbf{C 9 5 - 3 5 3 6 3}$ & $\mathbf{C 9 5 - 3 5 3 6 4}$ \\
\hline $\mathrm{C}$ & 66 & 66 \\
$\mathrm{H}$ & 10.7 & 10.9 \\
$\mathrm{~N}$ & 0.21 & 0.21 \\
$\mathrm{~S}$ & 1.3 & 1.04 \\
$\mathrm{Cl}$ (Energy Labs TXMethod 9076) & $12-12.1$ & 10.7 \\
$\mathrm{Cl}($ TOXMethod 9020B) & $12-13$ & Not \\
$\mathrm{Cl}$ (Commercial Lab) & & Analyzed \\
$\mathrm{Na}$ & 11.1 & 11.8 \\
$\mathrm{~K}$ & 0.52 & 0.51 \\
$\mathrm{~F}$ & 0.20 & 0.20 \\
$\mathrm{Si}$ & $2.9 \times 10^{-5}$ & $2.7 \times 10^{-5}$ \\
$\mathrm{O}$ (by difference) & 0.0046 & 0.0059 \\
\hline a. Subcontracted to Energy Laboratories. & 10 & 10 \\
\hline
\end{tabular}

Table 2. Target surrogate metals (ratio to TRIM@SOL).

\begin{tabular}{lcl}
\hline Metal & mg Metal/kg of TRIMQSOL & \multicolumn{1}{c}{ Added As $^{\mathrm{b}}$} \\
\hline $\mathrm{Ca}$ & 300 & $\mathrm{Ca}\left(\mathrm{C}_{2} \mathrm{H}_{3} \mathrm{O}_{2}\right)_{2} \cdot \mathrm{H}_{2} \mathrm{O}$ \\
$\mathrm{Fe}$ & 100 & $\mathrm{Fe}\left(\mathrm{C}_{2} \mathrm{H}_{3} \mathrm{O}_{2}\right)_{2}$ \\
$\mathrm{~Pb}$ & 1,676 & $\mathrm{~Pb}\left(\mathrm{C}_{2} \mathrm{H}_{3} \mathrm{O}_{2}\right)_{2} \cdot 3 \mathrm{H}_{2} \mathrm{O}$ \\
$\mathrm{Zn}$ & 1,367 & $\mathrm{Zn}\left(\mathrm{C}_{2} \mathrm{H}_{3} \mathrm{O}_{2}\right)_{2} \cdot 2 \mathrm{H}_{2} \mathrm{O}$ \\
$\mathrm{Ce}$ & 3,000 & $\mathrm{Ce}\left(\mathrm{C}_{2} \mathrm{H}_{3} \mathrm{O}_{2}\right)_{3} \cdot 1.5$ \\
& & $\mathrm{H}_{2} \mathrm{O}$ \\
\hline & & \\
a. As specified in letter of C. Shapiro of INEL to Stone \& Webster dated January 20, 1995. \\
b. These are acetates.
\end{tabular}


Table 3. TRIM@SOL test conditions.

MODAR Run Number

TRIM@SOL Processing Rate

Stoichiometric Air

TRIM®SOL Neutralization

Neutralizing Agent

In-oxidizer

Quench

In-oxidizer Concentrations

$\mathrm{Cl}$

$\mathrm{S}$

$\mathrm{K}$

Surrogate Metals Concentrations

$\mathrm{Ca}$

$\mathrm{Fe}$

$\mathrm{Pb}$

$\mathrm{Zn}$

$\mathrm{Ce}$

Oxidizer Liner

Operating Pressure

bar

Maximum Operating Temperature ${ }^{\circ} \mathrm{C}$

Steady State Feed Duration $\mathrm{kg} / \mathrm{h}$

\% Excess

$\mathrm{mg} / \mathrm{kg} \mathrm{H}_{2} \mathrm{O}$

$$
\mathrm{mg} / \mathrm{kg} \mathrm{H}_{2} \mathrm{O}
$$

None

$\mathrm{NaHCO}_{3}$

948

950

3.7

53

In quench only

57

In-oxidizer and

quench

3.8

$\mathrm{NaOH}$

$\mathrm{NaHCO}_{3}$

5600

540

4700

93

470

80

mg/kg TRIMßSOL

360

100

1950

1710

3550

290

90

1560

1290

2870

Metallic Ti Ceramic $\mathrm{TiO}_{2}$

Coating on $\mathrm{Ti}$

229

229

$600^{\circ}$

$619^{\circ}$

47

94 
Table 4. Phase I testing (overall results).

\begin{tabular}{|c|c|c|c|}
\hline MODAR Run Number & & 948 & 950 \\
\hline Total Feed Time & Hours & 47 & 94 \\
\hline Acid Formation Rate & $\mathrm{kg} \mathrm{HCl} / \mathrm{h}$ & 0.44 & 0.46 \\
\hline $\begin{array}{l}\text { In-Reactor Neutralization } \\
\text { Attained }\end{array}$ & & None Attempted & $75 \%$ \\
\hline Salt Generated in Oxidizer & kg & 3.5 & 68.3 \\
\hline Overhead Effluent pH & & 6.8 & 5.5 \\
\hline Brine $\mathrm{pH}$ & & 7.6 & 6.5 \\
\hline $\begin{array}{l}\text { Carbon Destruction } \\
\text { Efficiency }\end{array}$ & $\%$ & 99.97 & $>99.97^{\mathrm{a}}$ \\
\hline $\begin{array}{l}\text { Partitioning of Surrogate } \\
\text { Metals }^{\mathrm{b}}\end{array}$ & $\begin{array}{l}\text { \% Into Overhead Aqueous } \\
\text { Effluent } \\
\% \text { Precipitated }\end{array}$ & & \\
\hline $\begin{array}{l}\mathrm{Ce} \\
\mathrm{Pb} \\
\mathrm{Zn} \\
\mathrm{Fe} \\
\mathrm{Ca}\end{array}$ & & $\begin{array}{l}56 / 44 \\
73 / 27 \\
48 / 52 \\
7 / 92 \\
57 / 43\end{array}$ & $\begin{array}{l}38 / 62 \\
18 / 82 \\
28 / 72 \\
21 / 79 \\
45 / 55\end{array}$ \\
\hline \multicolumn{4}{|l|}{ Material Performance } \\
\hline $\begin{array}{l}\text { Oxidizer Liner } \\
\text { All Other Piping and Heat } \\
\text { Exchangers }\end{array}$ & & $\begin{array}{l}\text { Some Pitting } \\
\text { Excellent, } \\
\text { Unaffected }\end{array}$ & $\begin{array}{l}\text { Some Coating } \\
\text { Delamination } \\
\text { Excellent, } \\
\text { Unaffected }\end{array}$ \\
\hline $\begin{array}{l}\text { a. Based on Run } 949 \text { analysis. } \\
\text { b. Based on quantity analytically recover }\end{array}$ & & & \\
\hline
\end{tabular}


Table 5. Phase I testing-aqueous effluent quality organic analyses.

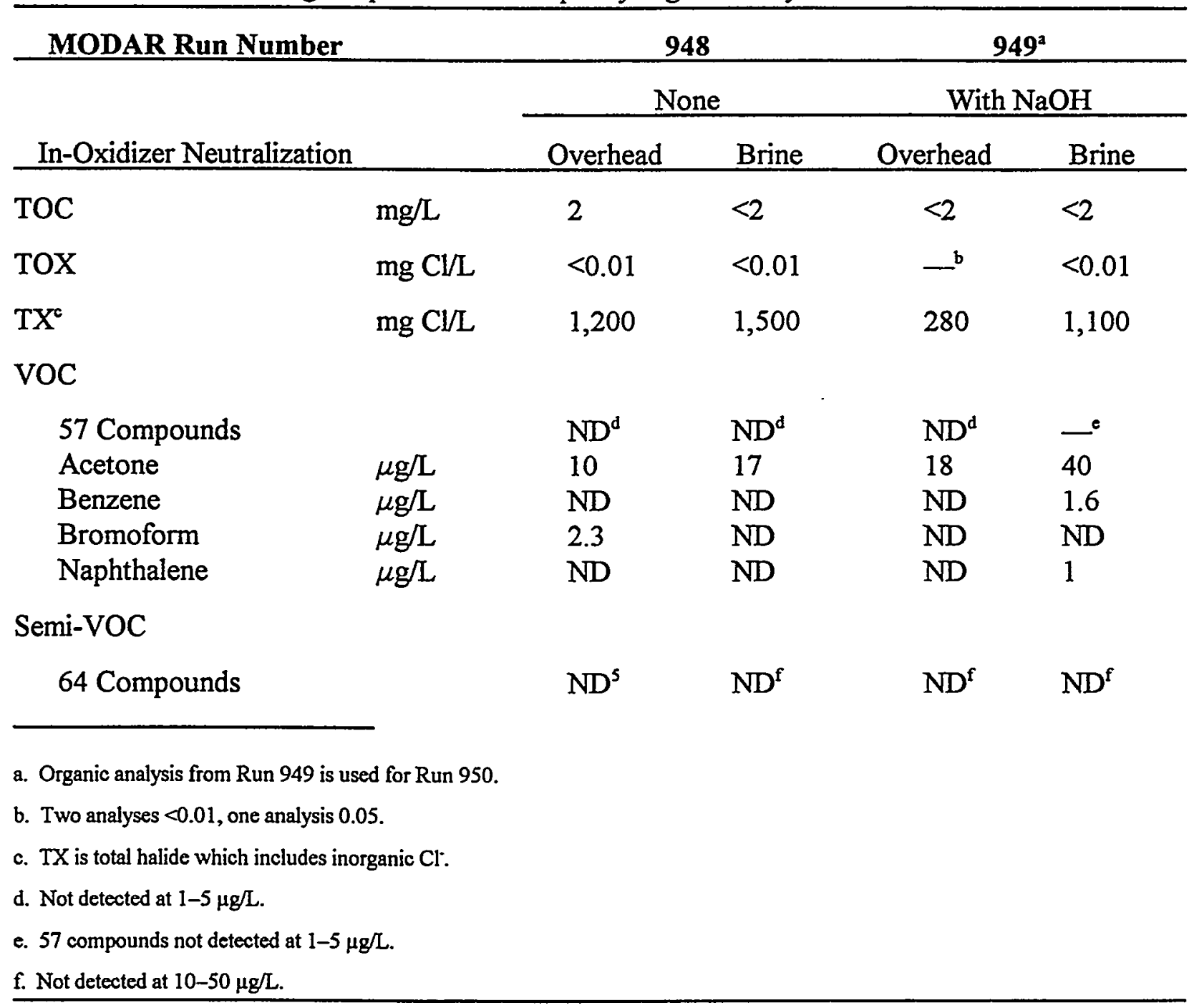


Table 6. Phase I testing-aqueous effluent quality inorganics in solution.

\begin{tabular}{|c|c|c|c|c|}
\hline \multirow{3}{*}{$\begin{array}{l}\text { MODAR Run Number } \\
\text { In-Oxidizer Neutralization }\end{array}$} & \multicolumn{2}{|c|}{948} & \multicolumn{2}{|c|}{950} \\
\hline & \multicolumn{2}{|c|}{ None } & \multicolumn{2}{|c|}{ With $\mathrm{NaOH}$} \\
\hline & Overhead & Brine & Overhead & Brine \\
\hline $\mathrm{Na}$ & 1,200 & 3,400 & 270 & 2,100 \\
\hline $\mathrm{K}$ & 10 & 76 & 4 & 110 \\
\hline $\mathrm{Cl}$ & 1,200 & 1,500 & 240 & 2,300 \\
\hline $\mathrm{SO}_{4}$ & 150 & 730 & 80 & 640 \\
\hline $\mathrm{Ce}$ & 2.5 & $<0.05$ & 0 & 0.06 \\
\hline $\mathrm{Pb}$ & 7.3 & 0.15 & 0.46 & 0.58 \\
\hline $\mathrm{Zn}$ & 8.0 & 17 & 2.4 & 16.30 \\
\hline $\mathrm{Fe}$ & 0.24 & $<0.05$ & $<0.04$ & $<0.04$ \\
\hline $\mathrm{Ca}$ & 1.4 & 1.6 & 1 & 4 \\
\hline $\mathrm{Ni}$ & $<0.05$ & 1.6 & $<0.04$ & 0.06 \\
\hline Mo & $<0.10$ & $<0.10$ & $<0.04$ & 0.05 \\
\hline $\mathrm{Ti}$ & $<0.01$ & $<0.01$ & $<0.04$ & $<0.04$ \\
\hline $\mathrm{Cr}$ & 0.08 & 0.07 & $<0.04$ & $<0.04$ \\
\hline $\mathrm{pH}$ & 6.8 & 7.6 & 5.5 & 6.5 \\
\hline TDS & 3,200 & 9,200 & 750 & 6,000 \\
\hline TSS & 37 & 120 & $<5$ & 72 \\
\hline
\end{tabular}


Table 7. Phase I testing-aqueous effluent quality solids analyses.

\begin{tabular}{|c|c|c|c|c|}
\hline \multirow[b]{3}{*}{$\begin{array}{c}\text { In-Oxidizer } \\
\text { Neutralization } \\
\end{array}$} & \multicolumn{2}{|c|}{948} & \multicolumn{2}{|c|}{950} \\
\hline & \multicolumn{2}{|c|}{ None } & \multicolumn{2}{|c|}{ With $\mathrm{NaOH}$} \\
\hline & Overhead & Brine & Overhead & Brine \\
\hline TSS & 37 & 120 & $<5$ & 72 \\
\hline $\mathrm{Na}$ & 23,000 & 6,200 & 4,500 & 13,000 \\
\hline $\mathrm{K}$ & 2600 & 830 & 0 & 11,000 \\
\hline $\mathrm{Ce}$ & 300,000 & 67,000 & 453,000 & 409,000 \\
\hline $\mathrm{Pb}$ & 240,000 & 152,000 & 4,600 & 170,000 \\
\hline $\mathrm{Zn}$ & 12,000 & 294,000 & 16,000 & 12,000 \\
\hline $\mathrm{Fe}$ & 14,000 & 13,000 & 27,000 & 14,000 \\
\hline $\mathrm{Ca}$ & 15,000 & 6,000 & 63,000 & 9,900 \\
\hline $\mathrm{Ni}$ & 1,300 & 22,000 & 15,000 & 2,700 \\
\hline Mo & 4,700 & 830 & 0 & 1,500 \\
\hline $\mathrm{Ti}$ & 260 & 560 & 15,000 & 1,100 \\
\hline $\mathrm{Cr}$ & 1,300 & 420 & 13,000 & 900 \\
\hline
\end{tabular}

Table 8 presents the averaged, steady state effluent gas quality. Excellent results were achieved with residual carbon monoxide in the range of 4 to 6 ppmv and $\mathrm{NO}_{\mathrm{x}}$ less than $0.5 \mathrm{ppmv}$.

\subsubsection{Neutralization}

As noted in Table 1; TRIMBSOL contained substantial concentrations of both chlorine and sulfur which generate strong acids upon oxidation. Although TRIM®SOL does contain the cations $\mathrm{Na}$ and $\mathrm{K}$, they were not present in sufficient concentration to completely self neutralize the acids associated with $\mathrm{Cl}$ and $\mathrm{SO}_{4}$.

MODAR intended to reform TRIM $@ S O L$ prior to its oxidation in the SCW oxidizer utilizing a newly patented process of heating the TRIM@SOL at elevated temperature and pressure in the presence of caustic and the absence of oxygen. The objective was to chemically split off TRIM@SOL's $\mathrm{Cl}$ and $\mathrm{S}$ and approach complete neutralization with $\mathrm{NaOH}$. A series of relatively short duration runs were conducted using this approach. It was determined in late July 
1995 that more of an optimization effort would be required than the project schedule would allow. Therefore, SCWODAT program personnel shifted to the two alternatives noted above: neutralization in the quench (Run 948) and neutralization in the oxidizer followed by neutralization in the quench as necessary (Runs 949 and 950). This alternative approach to the neutralization of acids formed during the oxidation of TRIM@SOL was first implemented during the SCWODAT program.

Table 8. Phase I testing-effluent gas quality.

\begin{tabular}{|c|c|c|c|}
\hline \multicolumn{2}{|c|}{ MODAR Run Number } & 948 & 950 \\
\hline \multicolumn{2}{|c|}{ In-Oxidizer Neutralization } & None & With $\mathrm{NaOH}$ \\
\hline $\mathrm{N}_{2}$ & Vol\% & 81 & 81 \\
\hline $\mathrm{O}_{2}$ & Vol\% & 13 & 13 \\
\hline $\mathrm{CO}_{2}$ & Vol\% & 5.7 & 5.2 \\
\hline $\mathrm{CO}$ & ppmv & 4 & 6 \\
\hline $\mathrm{N}_{2} \mathrm{O}$ & Vol\% & $<0.01$ & $<0.010$ \\
\hline $\mathrm{NO}_{\mathbf{x}}$ & ppmv & $<1.0$ & $<1.0$ \\
\hline
\end{tabular}

In all the tests, aqueous $\mathrm{pH}$ values were measured as follows:

- Overhead Effluent

- Measured continuously, on-line with an electrode that was calibrated every 8 hours

- Measured every hour on grab samples with a minimum of two ranges of $\mathrm{pH}$ paper

- Measured by Energy Laboratories on test composites.

- Brine Effluent

- Measured every hour on grab samples with a minimum of two ranges of $\mathrm{pH}$ paper

- Measured by Energy Laboratories on test composites. 
The extent of acid neutralization was indicated by the $\mathrm{pH}$ of the overhead effluent and brine streams exiting the SCWO process. If no neutralization had been achieved, the overhead effluent $\mathrm{pH}$ would have been approximately 1.5. Percent neutralization efficiency as a function of the logarithmic $\mathrm{pH}$ scale is approximately as follows:

\begin{tabular}{cc} 
Effluent pH & $\begin{array}{c}\text { Acid Neutralization } \\
\text { Efficiency } \\
(\%)\end{array}$ \\
\hline 1.5 & 0 \\
2.5 & 90 \\
3.5 & 99 \\
4.5 & 99.9 \\
5.5 & 99.99 \\
6.5 & 99.999
\end{tabular}

In Run 948, complete acid neutralization was achieved in both the overhead effluent and the brine. The pHs attained were 6.8 and 7.6 respectively (Table 4 ), with the quench water containing $0.57 \mathrm{wt} \% \mathrm{NaHCO}_{3}$ and the brine makeup containing $2.4 \mathrm{wt} \% \mathrm{NaHCO}_{3}$.

In Run 950, caustic was metered in with the TRIM $\otimes S O L$ feed to provide in-oxidizer neutralization. Seventy-five percent neutralization was achieved in the oxidizer and quench neutralization yielded a final overhead effluent $\mathrm{pH}$ of 5.5 (Table 4). The brine effluent $\mathrm{pH}$ was 6.5 .

\subsubsection{Distribution of Surrogate Metals and Inorganics}

The surrogate metals which were added to the process influent were: $\mathrm{Ce}, \mathrm{Pb}, \mathrm{Zn}, \mathrm{Fe}$, and Ca. In Run 948 , the actual feed concentrations were approximately $16 \%$ above the target concentrations. In Run 950 , they were $6 \%$ below the targets. All metals were added as reagent grade acetates. Supercritical water oxidation destroyed the acetate portion of the metals feed.

Tables 9 and 10 present the detailed information on the distributions of the inorganic elements and sulfate (the product of oxidation of sulfur) for Runs 948 and 950 . The fifth column lists the mass of the individual species delivered to the process. These were calculated from volumes pumped, fluid specific gravities, and constituent concentrations. The last column is the mass balance closure: element recovered by sampling and chemical analysis divided by mass of the element fed. In Run 948 all were within acceptable limits of closure (except $\mathrm{Fe}-$ see the table's footnote). This column, therefore, validates the sampling and chemical analysis techniques and methods. 
Table 9. Run 948 distribution of elements unneutralized TRIMßSOL (in the oxidizer).

Percent of Recovered

\begin{tabular}{cccccc} 
Element & Overhead & Brine & In-Oxidizer & $\begin{array}{c}\text { Total Mass } \\
\text { Fed (g) }\end{array}$ & $\begin{array}{c}\text { Element Recovered } \\
\text { Element Fed } \\
(\%)\end{array}$ \\
\hline $\mathrm{Na}$ & 80 & 19 & 1 & 19,500 & 110 \\
$\mathrm{~K}$ & 48 & 30 & 22 & 346 & 89 \\
$\mathrm{Cl}$ & 90 & 10 & 0 & 20,700 & 88 \\
$\mathrm{SO}_{4}^{\mathrm{a}}$ & 55 & 23 & 22 & 6,065 & 64 \\
$\mathrm{Ce}$ & 56 & 4 & 40 & 647 & 80 \\
$\mathrm{~Pb}$ & 73 & 11 & 16 & 361 & 97 \\
$\mathrm{Zn}$ & 48 & 36 & 16 & 296 & 86 \\
$\mathrm{Fe}$ & 7 & 2 & 90 & 22 & $930^{\mathrm{b}}$ \\
$\mathrm{Ca}$ & 57 & 8 & 35 & 65 & 88 \\
\hline
\end{tabular}

a. TRMMSOL contains $1.2 \mathrm{wt} \% \mathrm{~S}$ present as a petroleum sulfonate. The reaction product of SCWO is sulfate.

b. Forty-seven corrosion coupons, most containing iron, were mounted in the oxidizer vessel.

Table 10. Run 950 distribution of elements neutralized TRIM®SOL (in the oxidizer).

Percent of Recovered

\begin{tabular}{lccccc}
\cline { 2 - 6 } Element & Overhead & Brine & In-Oxidizer & $\begin{array}{c}\text { Total Mass } \\
\text { Fed (g) }\end{array}$ & $\begin{array}{c}\text { Element Recovered } \\
\text { Element Fed } \\
(\%)\end{array}$ \\
\hline $\mathrm{Na}$ & - & - & - & 64,800 & $\mathrm{NA}$ \\
$\mathrm{K}$ & 21 & 76 & 4 & 694 & 109 \\
$\mathrm{Cl}$ & 27 & 65 & 9 & 40,400 & 75 \\
$\mathrm{SO}_{4}{ }^{2}$ & & & & 12,200 & $\mathrm{NA}$ \\
$\mathrm{Ce}$ & 33 & 67 & 0 & 1,010 & 30 \\
$\mathrm{~Pb}$ & 11 & 76 & 13 & 550 & 45 \\
$\mathrm{Zn}$ & 25 & 45 & 30 & 453 & 76 \\
$\mathrm{Fe}$ & 20 & 34 & 46 & 32 & 97 \\
$\mathrm{Ca}$ & 48 & 37 & 15 & 102 & 119 \\
\hline a. TRMMSOL contains 1.2 wt\% S present as a petroleum sulfonate. The reaction product of SCWO is sulfate.
\end{tabular}


The mass balances noted above for the elements and anions listed were calculated using the procedure described here. As an example, consider the element cerium, $\mathrm{Ce}$.

Input Mass of $\mathrm{Ce}$.

Grams $\mathrm{Ce}=$ Aqueous feed flow $(\mathrm{mL} / \mathrm{min}) \times$ Ce concentration ${ }^{\mathrm{b}}(\mathrm{g} / \mathrm{L}) \times$ Run time $(\mathrm{min}) \times 1$ $\mathrm{L} / 1,000 \mathrm{~mL}$

\section{Output Mass of Ce.}

Grams $\mathrm{Ce}=$ Overhead effluent flow $^{\mathrm{a}}(\mathrm{mL} / \mathrm{min}) \times$ Ce concentration $^{\mathrm{c}}(\mathrm{g} / \mathrm{L}) \times$ Run time $(\mathrm{min}) \times 1$ $\mathrm{L} / 1,000 \mathrm{~mL}$

+ Brine flow $(\mathrm{mL} / \mathrm{min}) \times$ Ce concentration ${ }^{c}(\mathrm{~g} / \mathrm{L}) \times$ Run time $(\mathrm{min}) \times 1 \mathrm{~L} / 1,000 \mathrm{~mL}$

+ Brine drain $^{d}(L) \times$ Ce concentration ${ }^{c}(g / L)$

$(g / L)$

+ Sum of various separate rinses $^{c}(\mathrm{~L}) \times\left[\mathrm{Ce}_{\text {concentration }}{ }^{\mathrm{c}}(\mathrm{g} / \mathrm{L})+\right.$ Suspended solids $^{c}$

$$
\left.\times \text { Ce concentration }^{\mathrm{c}}(\mathrm{g} / \mathrm{g} \text { solids })\right]
$$

In Run 950 (See Table 10), the balance closures for $\mathrm{K}, \mathrm{Cl}, \mathrm{Zn}, \mathrm{Fe}$, and $\mathrm{Ca}$ were considered reasonable due to the range of the \% recovered (75-109\%). Deficiencies for $\mathrm{Pb}$, and particularly $\mathrm{Ce}$, should be noted (30-45\%). After calculating a similar cerium mass balance deficiency in Run 949, MODAR spiked several samples with known amounts of cerium sulfate, cerium oxide, and cerium carbonate. The analytical results on these known addition samples pointed toward problematic analyses of cerium oxide. Both Energy Laboratories and INEL's laboratory observed this difficulty.

In Tables 9 and 10 all the element distributions were based on normalizing the analytically recovered quantities to 100 percent. The location or locations of the missing mass of $\mathrm{Pb}$ and $\mathrm{Ce}$ in Run 950 could not be determined.

Table 4 best summarizes the partitioning of the metals. When $\mathrm{NaOH}$ was not present in the oxidizer, Run 948, approximately 60 percent of the surrogate metals went overhead. When $\mathrm{NaOH}$ neutralization was conducted in the oxidizer, only about 30 percent went overhead. This

${ }^{8}$ Average flow rate during test.

bAverage of Energy Labs or INEL Ce analysis of the feed solution and the calculated value from the "as formulated" in the MODAR laboratory.

'Energy Labs or INEL analysis.

'Drained from the bottom of the oxidizer after the test run.

'At the conclusion of each test various drains and rinses were performed. These were sampled, collected, measured, and analyzed separately. 
was most likely due to the lower solubility of the metal compounds formed under lower acid conditions. It is not understood if the cerium was more prone to form $\mathrm{CeCl}$ in the unneutralized environment and was therefore picked up in the effluent analysis while the cerium was more prone to form $\mathrm{CeO}_{2}$ in the neutralized environment and wasn't measured in the effluent.

In neither processing mode was there a clean split of the surrogate metals between the overhead effluent and the brine. The Fe result in Run 948 was an anomaly caused by the presence of a large number of iron containing corrosion coupons in the oxidizer. These coupons were added with the permission of DOE/INEL at the request of MTT which was conducting SCWO materials of construction studies.

Supercritical water oxidation of TRIM@SOL precipitates "sticky salts" whether or not a neutralizing agent was added to the oxidizer influent. TRIM@SOL, as previously noted, contains $\mathrm{Na}, \mathrm{K}, \mathrm{Cl}$, and $\mathrm{S}$ which generate sticky chloride and sulfate salts. Due to the large quantities of carbon dioxide present, carbonates were also formed if excess cation was present.

At approximately the 40 and 80 hour marks of Run 950 , the TRIMQSOL, surrogate metals, and caustic feed flows were interrupted to rinse the salts out of the oxidizer. This was accomplished by raising the cool brine level and then draining it out the brine letdown train. This procedure was not used at the end of the test. Table 10 indicates that rinsing may have decreased the accumulation of cerium (the surrogate for plutonium) in the oxidizer. However, it is important to recall the poor cerium mass balance closure in Run 950. No rinsing was conducted in Run 948.

\subsection{Component Performance}

The following sections provide detailed descriptions of the performance of various components throughout the SCWODAT program.

\subsubsection{Liner Performance}

The following sub-sections provide a detailed account of the liner performance for the SCWODAT program.

5.3.1.1 Perforation of Liner No. 1 in Run 949. In SCWODAT Runs 946-949, TRIMQSOL was used, with the surrogate metals $\mathrm{Ce}, \mathrm{Pb}, \mathrm{Zn}, \mathrm{Fe}$, and $\mathrm{Ca}$ in the form of acetates and with and without in-situ neutralization. The form of the metals in the actual waste to be treated in the future is unknown. Prior to Run 949, Liner No. 1 had not shown signs of severe degradation except for small titanium Grade 2 sections above the brine level. The Grade 12 base metal and welds performed remarkably well. Previous damage can be described as occasional shallow pits, primarily in the base metal. 
In Run 949, Liner No. 1 suffered severe corrosion which occurred at numerous locations on the I.D. surface of the liner above the brine level. The corrosion resulted in multiple perforations over a 3-ft high section, starting approximately $1 \frac{1}{2} \mathrm{ft}$ below the quench port level. A severe attack was also observed on the outside surface of the nozzle purge shell below the flange; at the time the shell was made from titanium Grade 2.

At each severely attacked location of the liner, large dark nodules formed; these protruded above rather uniform, seemingly dense, lighter colored salt deposits.

An extremely strong odor normally associated with hydrogen sulfide emanated from the liner and lingered for hours. A subsequent examination clearly demonstrated that the odor was associated with the nodules. A piece separated from one of the nodules was placed in a scanning electron microscope chamber, and the chamber could not be evacuated. The copper-alloy holder was discolored around the sample within a matter of minutes. Apparently, the piece still retained hydrogen sulfide, a week after removal from the oxidizer vessel.

As a part of an investigation to determine the cause of the severe attack in Run 949, the following examinations of selected samples were performed:

- $\quad$ Scanning electron microscopy (SEM)

- $\quad$ Energy dispersive spectroscopy (EDS)

- Wave-length dispersive spectroscopy (WDS).

The objectives of the examinations were to obtain information which could help to determine the most likely mechanism of the severe corrosion and identify the most likely contributor to acceleration of corrosion attack in Run 949.

Four samples: Sample (1) char-like material from the I.D. side of the liner over a perforation including the nodule; Sample (2) deposit from an unattacked area; Sample (3) titanium sample including an attacked area cut from the liner wall; and Sample (4) char-like material from perforation sites collected near O.D. were examined in a JEOL Superprobe 733, with the participation of SCWODAT program personnel, at the Geller MicroAnalytical Laboratory in Topsfield, MA, where the examinations (SEM, EDS, and WDS) were performed. In examining the deposits/corrosion products, the intent was to characterize the local chemistry of the surfaces which had been in contact with the liner surface. The findings are summarized in Table 11. 
Table 11. Summary of results from examinations at Geller Laboratories.

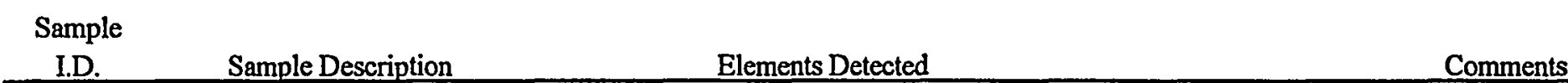

1 Deposit/corrosion product over a "pit"

Prevalent: $\mathrm{Cl}, \mathrm{Na}, \mathrm{Ti}$

Spots containing $\mathrm{Zn}, \mathrm{S}, \mathrm{Pb}$, and $\mathrm{Ce}$

2

Deposit from unattacked area

Prevalent: $\mathrm{Cl}, \mathrm{Ti}, \mathrm{Na}, \mathrm{S}$.

Mo was positively identified in one of the four areas examined.

Spots containing $\mathrm{Ce}$.

$\mathrm{K}$ and $\mathrm{Ni}$ show as very low intensity peaks in some of the spectra.

3 Ti 12 including an attacked area

$4 \quad$ Black char-like material collected from various perforation sites near the O.D. surface of the liner
Apart from $\mathrm{Ti}, \mathrm{Cl}$ was detected at virtually all examined spots.

The following elements were detected at least at 3 of the 7 examined spots: $\mathrm{Ca}, \mathrm{K}$, and $\mathrm{O}$.

Other elements detected at some of the analyzed spots: $\mathrm{S}, \mathrm{Pb}, \mathrm{Ni}, \mathrm{Fe}, \mathrm{Zn}$, and $\mathrm{Ce}$.

Prevalent: $\mathrm{Cl}, \mathrm{Na}, \mathrm{Ti}$.

A strong $\mathrm{Pb}$ peak in a spectrum taken from one of numerous scattered "specks."

$\mathrm{K}$ shows in all 3 spectra taken with a

pronounced peak in one of them.

$\mathrm{Fe}$ and $\mathrm{Ni}$ show locally as very low intensity peaks in a spectrum taken from one of the yellowish spots.
No oxygen. Apparently only chloride salts of $\mathrm{Na}, \mathrm{Ti}, \mathrm{Pb}$, and $\mathrm{Ce}$ except for spots containing $\mathrm{Zn}$ and $\mathrm{S}$ where $\mathrm{ZnS}$ was probably present. Peaks of $\mathrm{Zn}$ and $\mathrm{Ce}$ where present are quite pronounced.

The sample still contained a fair amount of what appeared to be $\mathrm{H}_{2} \mathrm{~S}$ as evidenced by (1) intensive gassing out in the SEM chamber during an attempt to evacuate it and (2) rapid brightening of a bronze disk around the sample when the latter was placed on the disk

\section{Mo peak overlaps with $S$ \\ A barely detectable oxygen peak at local spots}

In one case, $\mathrm{Pb}$ and $\mathrm{S}$ were confirmed by the wave dispersive spectroscopy while in other cases sulfur and possibly coincident Mo were detected; all three elements overlap in energy dispersive spectra. Where $\mathrm{Pb}$ was present, mapping indicated a correlation between $\mathrm{Pb}$ and $\mathrm{Cl}$ incidence.

No oxygen. No $\mathrm{S}$ or $\mathrm{Mo}$ which normally overlap with $\mathrm{Pb}$ in an EDS spectrum. 
In these examinations, the predominant elements present in the samples were as follows (listed in the order of relative intensity of the peaks on the spectra):

- $\quad$ Sample (1) $\mathrm{Cl}, \mathrm{Na}, \mathrm{Ti}$

- $\quad$ Sample (2) $\mathrm{Cl}, \mathrm{Ti}, \mathrm{Na}, \mathrm{S}$

- Sample (3) $\mathrm{Ti}, \mathrm{Cl}$

- Sample (4) Cl, Na, Ti.

Oxygen was detected only in samples (2) and (3). Sample (2) apparently contained only small amounts of oxygen based on an observation of a barely detectable oxygen peak at local spots. No oxygen was detected in samples (1) and (4).

Other elements detected in the samples were as follows:

- $\quad$ Sample (1) $\mathrm{Zn}, \mathrm{S}, \mathrm{Pb}, \mathrm{Ce}$

- $\quad$ Sample (2) Ce, Mo, K, Na

- Sample (3) Ca, K, S, Pb, Ni, Fe, Zn, Ce

- $\quad$ Sample (4) Pb, K, Fe, Ni.

Five elements representing the surrogate metals are in bold to show their distribution between the samples. Iron could also have come from the liner base metal.

In addition, two samples removed from the liner, one representing deposit/corrosion product at a perforation and the other representing liner material and containing deposits away from a perforation, as well as one titanium U-bend specimen exposed to the supercritical zone environments in Phase I of the SCWODAT program, were examined at the INEL.

The results of examinations of these three samples at the INEL agreed with the data from Geller Laboratories.

Discussion of the Laboratory Examination Results-The corrosion product/deposit from a perforated area, i.e., sample (1), as well as the deposit from an unattacked area, i.e., sample (2), contained primarily chlorine, sodium, and titanium, at least in the layer near the interface with the liner. There was no evidence of oxides in samples (1) and (4) based on the surface examinations capable of detecting oxygen. Thus, it would appear that the corrosion product and near-interface layer of the deposits were rich in sodium chloride and at least one of the titanium chlorides. Since 
no X-ray diffraction was done on samples (1) and (4), it is far from clear in what form Ti was present in the deposits.

A fairly high concentration of sulfur was detected only in the deposit at an unattacked area. Only small amounts of sulfur were present at the perforation where the examined samples were taken. The hydrogen sulfide odor suggests that locally, under the deposits, there were reducing conditions.

A significant amount of metals added to the feed were found in the deposits, corrosion product, and on the surface of the titanium Grade 12 sample. The following metals were detected in the examinations: $\mathrm{Ti}, \mathrm{Na}, \mathrm{Zn}, \mathrm{Pb}, \mathrm{Ce}, \mathrm{Fe}, \mathrm{Mo}, \mathrm{K}, \mathrm{Ni}$, and $\mathrm{Ca}$.

Some of the detected metals were a part of the titanium Grade 12 chemistry; others, i.e., $\mathrm{Zn}$, $\mathrm{Pb}, \mathrm{Ce}, \mathrm{Fe}$, and $\mathrm{Ca}$ apparently came from the feed where they were introduced as surrogate metals. Ni could have come from the high-nickel alloys in the feed system parts, the liner base metal, and/or corrosion specimens. $\mathrm{Na}$ and $\mathrm{K}$ apparently came from the waste feed and from the neutralizing agent.

The severe attack of the titanium liner can be attributed to a special case of underdeposit, or crevice corrosion which resulted in the formation of large and deep "pits." Crevice attack is known to occur in chloride and sulfate solutions and is enhanced by cathodic depolarizers such as dissolved oxidizing species, including $\mathrm{Fe}^{+3}, \mathrm{Ni}^{+2}, \mathrm{Ti}^{+4}, \mathrm{Ce}^{+4}$, and $\mathrm{H}^{+}$ions. (R. W. Schulz, "Understanding and Preventing Crevice Corrosion of Titanium Alloys-Part I," Materials Performance, V. 31, No. 10, pp. 57-62, 1992.)

Some other cations, such as $\mathrm{Zn}^{+2}$ and $\mathrm{Ca}^{+2}$ can aggravate localized corrosion and result in a special form of localized corrosion resembling crevice corrosion, except that initiation may occur in the absence of normal crevices.

Susceptibility of titanium to underdeposit corrosion was apparently enhanced by the presence of some of the metals near the areas at the interface between the titanium surface and deposits where highly reducing conditions could have been created leading to the severe attack and perforations observed in Run 949.

5.3.1.2 Post-test Visual Examinations of the Coated Liner No. 2. A multilayer graded coating was applied by thermal spray onto the internal diameter of titanium Liner No.2. Liner No. 2 was used in Run 950, removed after the run, and visually inspected. The cumulative exposure of Liner No. 2 to high temperatures was 129 hours. Visual examinations of the liner inside surfaces after the run were performed independently by Zatorski Coatings and by Stone \& Webster. The examinations determined that parts of the coating had detached and/or had shown cracking. The coating failures occurred primarily in the same areas that presented problems during the application of the coating, i.e., "in the lower half of the liner over a circumferential band 
approximately mid-way in the cylindrical section. There was lifting of the coating in smaller sections in other areas, again primarily in the lower half of the liner. In the upper half of the liner, coating detached in two areas: one area at the edge, i.e., near the lower face of the liner upper half and one area near the quench port.

Observations of coating failures on the inside surfaces of the lower and upper halves of the liner are described below by the areas starting from the bottom of the liner upwards. Possible causes are discussed for each of these areas.

\section{Lower Half of the Liner No. 2-}

- Observation-Some minor lifting of the coating over an arc of less than 30 degrees along the circumferential weld at the joint of the conical section to the cylindrical section.

Possible Causes-Stress in the coating from deposition on irregular surfaces of the weld or at sharp local geometry changes. Possible use of steel brushes in the finishing of the weld and resulting iron embedment in the weld was also suggested as a plausible cause.

- Observation-Gross lifting of the coating around the circumference within 10 to 30 $\mathrm{mm}$ wide bands. These bands extended from less than 30 degrees to over 180 degrees around the circumference. The axial length of the affected area was over $300 \mathrm{~mm}$. In this area, some of the coating flaked off completely.

Possible Causes-Continued peeling of the substrate in the same manner as occurred during the grit blast operation. Another plausible cause could be overheating of the coating during deposition. This second cause is unlikely since the temperature during deposition on the lower half was monitored in the same fashion as in the upper half of the liner and the temperatures were the same within $10^{\circ} \mathrm{C}$.

- Observation-Minor lifting of the coating along the top edge in more than one area. Each of these areas extended over an arc of less than 15 degrees.

Possible Cause-Thermal stresses from differential thermal expansion at an edge. This can be solved by wrapping the coating around the edge or beveling the edge. The edge can also be rounded. 


\section{Upper Part of the Liner No. 2-}

- Observation-Minor lifting at the bottom edge along an arc less than 15 degrees along the circumference.

Possible Cause-Stress from differential thermal expansion at an edge. This can be solved by wrapping the coating around the edge or beveling the edge. The edge can also be rounded.

- Observation-Lifting in the area below the quench port in a patch approximately 50 $\mathrm{mm}$ by $70 \mathrm{~mm}$.

Possible Causes-Peeling of the substrate or localized overheating of the coating during deposition. Overheating could be associated with the placement of the cooling jets on the arc-plasma gun assembly. Potential for overheating can be mitigated by the placement of additional cooling jets on the gun assembly.

The possible root causes of the substrate lifting were (1) defects in the titanium sheet, e.g., alpha-casing or severe hydriding, (2) embedded ferrous material transferred onto the titanium surface during rolling, forming, or finishing operations, or (3) embedded foreign materials introduced during the surface roughening by grit blasting prior to coating. Stress corrosion cracking due to propanol used during cleaning was also suggested as a possibility.

The condition of the substrate and its possible effect on the performance of the liner coating have not been investigated. Such an investigation requiring detailed metallurgical laboratory examinations would help establish the root cause of the coating failures and help eliminate the problem in future applications. The coating failures could have been attributed to the titanium liner fabrication process. The fabrication history including forming and finishing was not fully known. The weld shop could have used ferrous rollers to roll the sheets. The cleanliness of the rolls was not known. Optical microscopy reinforces this hypothesis since the titanium sheet at magnifications over $200 \mathrm{X}$ showed defects at the surface in the form of fine cracks forming delaminations nearly parallel and extending to the surface. The cracks terminate at a line of large second phase particles or a line of oxide particles. These cracks and defects appear clearly in both the as-received titanium sheet and in the coated and tested sheet. ${ }^{5}$

The other possibility, of embedding foreign material during the grit blasting is unlikely since the cleanliness and composition of the grit was known and both halves were prepared at the same time using the same blast setup and operator.

The lifting of the coating during service can be also indicative of coating or substrate overheating during the coating application. The temperature during coating application was monitored using an $\mathbb{R}$ technique which measured the back side temperature of the substrate. This 
temperature measurement method would not detect small fluctuations on the coating side. The possible causes of overheating are localized temperature fluctuations due to (1) variations in the spray distance, (2) cooling jet fluctuations or (3) gun parameter changes.

As to the first possibility, gun-to-substrate spray distance variations were determined by the mechanical setup. No changes in the spray distance were noted based on visual observations during coating application. In future applications, in-process recording of the spray distance is recommended. The second possibility, cooling jet fluctuations, can be detected by recording the flow or pressure during coating application. This is recommended in future thermal spray applications. The third possibility, gun parameter changes; were unlikely since the spray parameters were in closed-loop control, and the system detects and records any parameter changes.

While the coating failed in a number of areas, a significant portion of the coating, particularly in the upper half appeared to have remained intact. SCWO environment exposure tests of the coating should be continued once the root cause of substrate flaking is determined. Measures to be taken to avoid problems associated with geometry (sharp edges, irregular surfaces etc.) should be coordinated with the design and fabrication activities. 

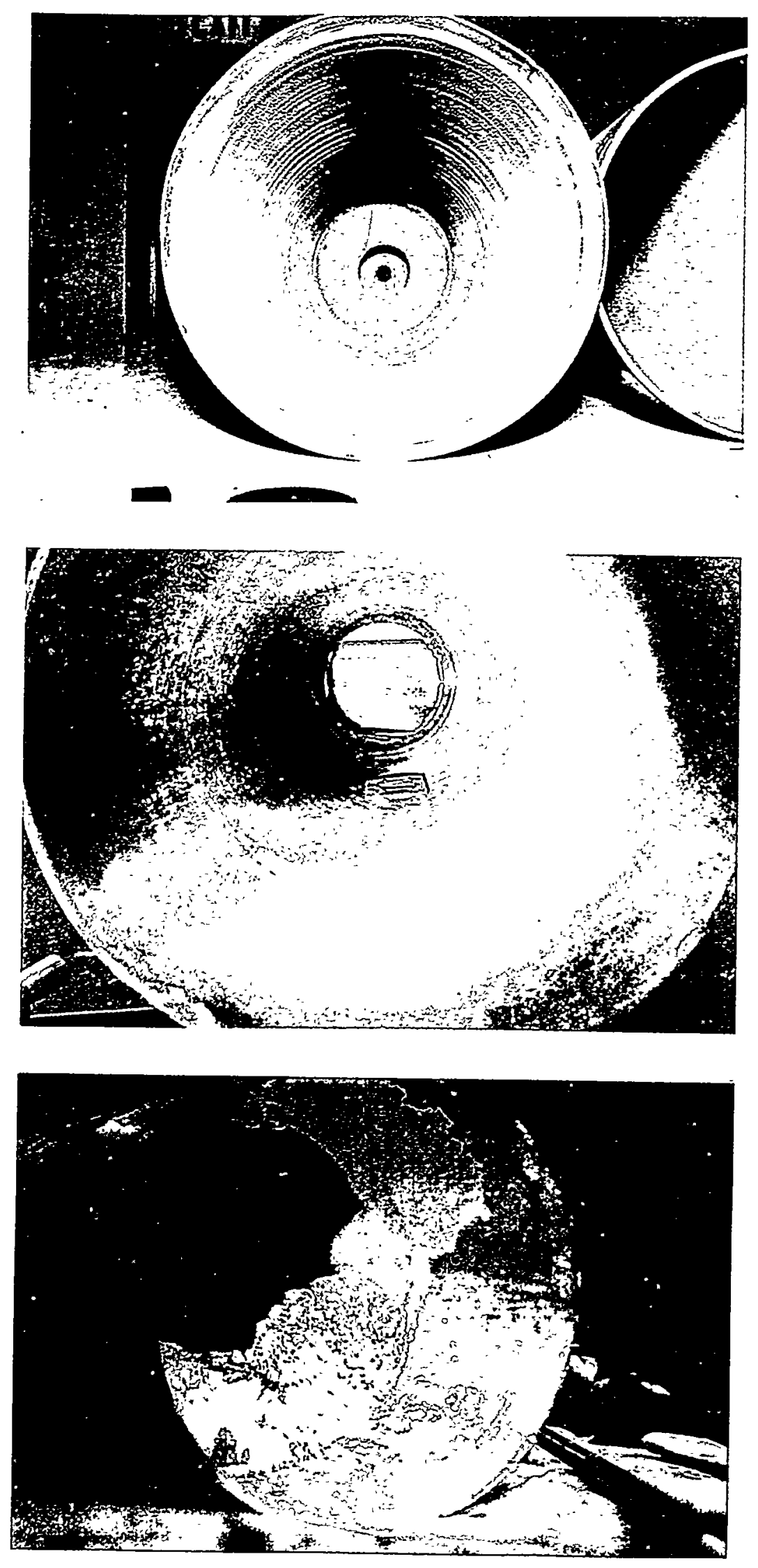

Figure 5. The ceramic coated liner was used in Run 950. a) Lower liner before use b) Upper liner after Run 950 c) Salt deposition on the liner after Run 950 

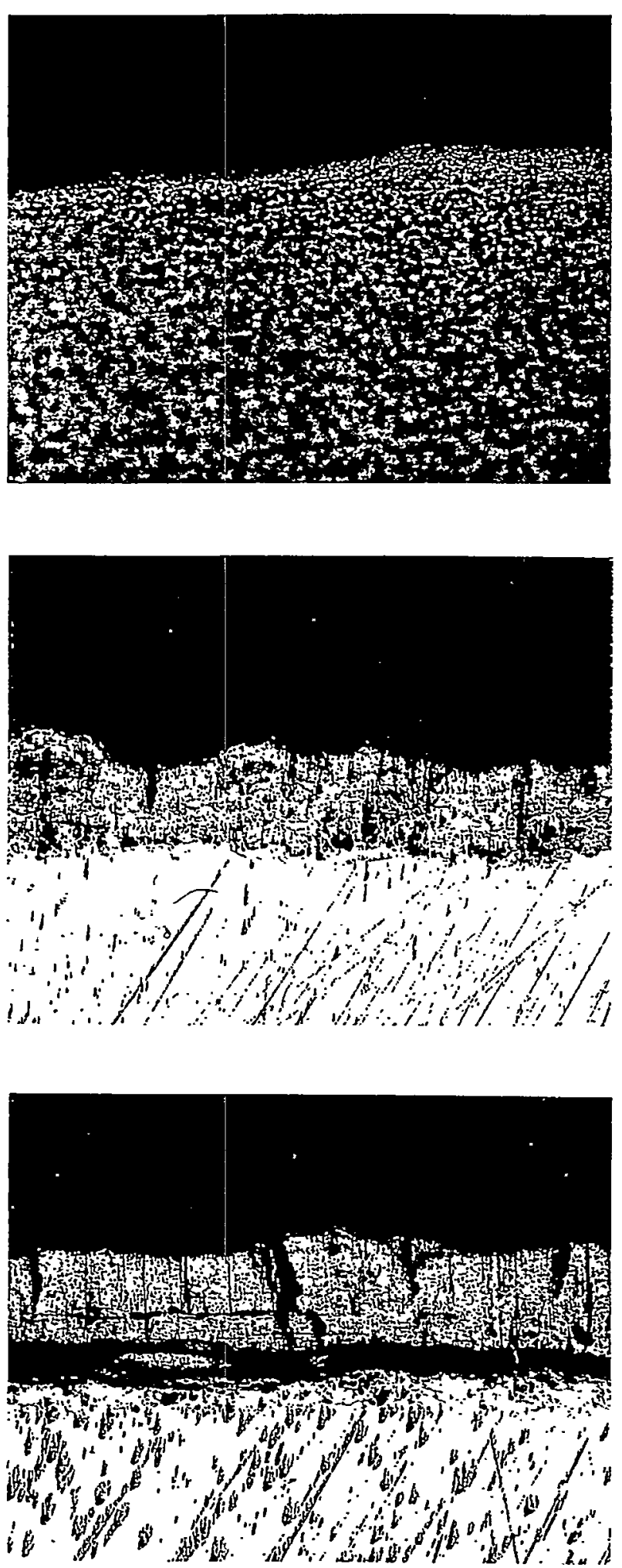

Figure 6 The titanium / ceramic interface: a) A section of titanium that was used to make the liner shows possible preexisting conditions b) The ceramic coating intact from the lower half of the liner c) Separation of the ceramic coating from the titanium liner in the area of blistering. 
5.3.1.3 Liner No. 1 after Repairs. Liner No. 1 suffered severe corrosion during Run 949. The decision was made to repair Liner No. 1 to support the Navy waste testing portion of the SCWODAT program. Prior to the Navy waste testing the part of Liner No. 1 which contained perforations was cut off approximately 2 in. above the conical bottom section. A cylindrical replacement piece was fabricated from new titanium Grade 12 sheet, rolled and seam-welded sections and welded to the salvaged bottom part. This bottom part has been in service since the first titanium Grade 2 liner was installed in the Summer of 1993 and has performed well.

The refurbished Liner No. 1 was used in all the runs of the Phase II Navy waste testing (Runs 951-955B). The refurbished Liner No. 1 was inspected visually in December 1995 upon completion of the Phase II Navy waste testing. All deposits had been removed from the liner prior to the inspection, except for some remaining sticky solid deposits at the bottom of the liner. These solid deposits formed, according to MODAR, primarily during the Navy composite waste test. In individual waste runs, powdery, much less sticky, relatively light deposits were reported.

On the inside surface of the refurbished Liner No. 1, there was a fairly thin scale-like deposit ranging in color from light pink to cream. In the areas where this scale was missing, there was no apparent corrosion below mark 29" (distance from the top of the liner), very little corrosion between mark 19" and mark 29", and pronounced pitting between mark 9" and mark 19". Above mark 9", there was no pitting and most scale was intact. Over the 10 -in. high area between mark $9 "$ and mark 19", there were areas of a fairly extensive "general" corrosion. The corrosion could be described as clusters of multiple overlapping pits as well as a number of isolated wide open pits. The depth of attack in most cases was close to or under 1/64 inch, but some were as deep as $1 / 32$ inch. Corrosion affected both titanium base metal and in the seam weld; the severity of attack in the weld metal and in the base metal were comparable.

Corrosion to refurbished Liner No. 1 could have occurred primarily in Run 952 when solled "non-chlorinated" solvents were treated and the resulting oxidizer $\mathrm{pH}$ was very low before corrective actions were taken to raise the oxidizer $\mathrm{pH}$.

\subsubsection{December 1995 Inspection of Other Pilot Plant Components}

A visual inspection of selected critical components of the pilot plant was performed upon completion of the SCWODAT testing. The objective of the inspection was to characterize performance of the pilot plant components by visual examinations.

The components were examined with the naked eye, with the aid of magnifying glasses ( $3 \mathrm{X}$, $5 \mathrm{X}$, and $8 \mathrm{X}$ ), and, when required, with a baroscope. The following components/areas were examined:

- Inside surfaces of the oxidizer pressure vessel 
- Inside surfaces of the filter arms

- Inside and outside surfaces of the uncoated, refurbished Liner No. 1

- Quench mouth

- Quench purge shell

- Quenched effluent line inlet end

- Quenched effluent line outlet end and quench cooler inlet end

- Nozzle purge shell and end plate

- Feed nozzle and end face of the nozzle core tube.

A summary of essential observations made in the course of this inspection follows:

Oxidizer Pressure Vessel and Filter Arms. The inside diameter surfaces of the oxidizer pressure vessel and filter arms were examined visually where accessible and with a baroscope. The oxidizer vessel was examined prior to and after rinsing. Even prior to rinsing, the vessel inside surfaces were generally clean, except for deposits at the very bottom of the vessel. Similar deposits were observed at the bottom of the refurbished Liner No. 1. In the top section of the oxidizer, i.e., in the flange area, a few white streaks formed on the inside surface. Staining was observed on the oxidizer vessel inside surface under the filter arm openings, apparently due to a flow of a particulate-laden fluid from the bottom of the filter arms. Similar staining was observed on the lower part of both filter arms between 3 and 9 o'clock, i.e., up to what appeared to be a waterline. Above the waterline, there was a thin reddish deposit. At the very bottom of the filter arms, there was accumulation of light grey, fairly fine particulates around the $60^{\prime}$ clock position.

All observations of pitting on the inside surfaces of the oxidizer were compared to the detailed notes taken in previous inspections of the vessel and filter arms. No additional pitting, noticeable growth of previously formed pits, or any other type of corrosion attack was detected. That is, all pitted areas appeared to be unchanged since the inspections performed prior to the SCWODAT program.

The weld joining the vessel "shell" to the top flange did not show any signs of degradation. This weld was made during the 1995 repairs of the vessel, just before the start of the SCWODAT program and, thus, was exposed only to the environments which existed between the vessel and liner during the SCWODAT program. 
Thus, during the SCWODAT program, the environment behind the liner was apparently benign, and no additional degradation of the vessel including the filter arms occurred.

Quench Fitting. At the time of the inspection, the quench fitting opening was partially obstructed with a powdery substance which was readily removed. The inside diameter surface was difficult to examine through the opening but a small area which could be examined appeared to be in good condition, i.e., it did not show any signs of localized corrosion or erosion. The end face of the quench mouth retained original machining marks. A more detailed evaluation of the inside diameter surface would require sectioning of the tube to expose the I.D. surface.

Quench Purge Shell. A few scattered pits developed on the machined flange surface. Other surfaces accessible for visual inspection did not show any evidence of corrosion.

Quenched Effluent Line. Only the quench line inlet and outlet ends were examined. The inlet end was partially obstructed with a yellowish powdery substance which was readily removed with a toothbrush. The end faces and the inside diameter surfaces accessible for visual examination appeared intact.

Quench Cooler Inlet. The quench cooler inlet did not show any signs of plugging. The inside diameter surface was covered by a thin uniform layer of pink deposit. There was no evidence of localized or general corrosion.

None of the components from the quench mouth, downstream to and including the cooler, required any repairs and/or replacements throughout the entire program from Run 943 to Run 955B.

Nozzle Purge Shell and End Plate. The original component fabricated from titanium Grade 2 was in service in Runs 943 through Run 949. In Run 949, it suffered a severe corrosion attack. The replacement component fabricated from titanium Grade 12 was used in runs 950 through 955B.

An inspection of the component upon completion of the Navy Wastes Testing showed a pronounced non-uniform corrosion on the outside diameter surface of the shell and the bottom of the end plate, or flange. Severity of corrosion in the base metal and in the longitudinal seam weld metal was comparable. The depth of attack was up to 0.08 inch.

Based on a cursory inspection of the replacement purge shell and end plate by MODAR personnel after Run 950, some of the corrosion occurred during this run. Additional corrosion occurred most likely in the Run 952 when so-called "non-chlorinated" solvents were treated and the resulting oxidizer $\mathrm{pH}$ was very low before corrective actions were taken to raise the $\mathrm{pH}$. 
Feed Nozzle and End Face of the Nozzle Core Tube. The feed nozzle was in service from Run 945 through run 955B. Only the outside diameter surface of the feed nozzle was examined. In its lower part, which had been protruding into the oxidizer, there were areas which can be described as "locally uniform" corrosion. A few shallow pits had developed on the conical surface near the bottom of the feed nozzle.

The feed nozzle core tube was in service throughout the entire program, i.e., Runs 943 through 955B. Only its end face could be examined; it did not show any pronounced degradation. 


\section{REFERENCES}

1. Garcia, K. M., and Mizia, R., "Corrosion Investigation of Multilayered Ceramics and Experimental Nickel Alloys in SCWO Process Environments," Idaho National Engineering Laboratory Publication INEL-95/0017, February 1995.

2. SCWO Data Acquisition Project Test Plan May 1995, Stone \& Webster Engineering Corp and MODAR, Inc. (Proprietary).

3. Stone and Webster Data Acquisition Test Final Report, April 1996, Stone \& Webster Corp and MODAR, Inc. (Proprietary) .

4. Schulz, R. W., "Understanding and Preventing Crevice Corrosion of Titanium Alloys-Part I," Materials Performance, V. 31, No. 10, pp. 57-62, 1992.

5. Letter from R. Zatorski tp K. Garcia.

6. Letter from D. A. Johnson to K. Garcia, Subject: black precipitate.

7. Letter from D. A. Johnson to K. Garcia, Subject: analysis of Run 950.

8. Dehmel, J. C., Hong, G. T., "A Comparative Risk Assessment of Incineration and SCWO for Mixed Waste," Health Physics Society, February 1994.

9. Energy Labs analysis reports. 